\title{
Analysing land and vegetation cover dynamics during last three decades in Katerniaghat wildlife sanctuary, India
}

\author{
V S Chitale ${ }^{1,2, *}$ and M D Behera ${ }^{1}$ \\ ${ }^{1}$ Spatial Analysis and Modeling Laboratory, Centre for Oceans, Rivers, Atmosphere and Land Sciences \\ (CORAL), Indian Institute of Technology, Kharagpur 721 302, India. \\ ${ }^{2}$ International Centre for Integrated Mountain Development (ICIMOD), GPO Box 3226, Khumaltar, \\ Lalitpur, Kathmandu, Nepal. \\ *Corresponding author.e-mail: vschitale@iitkgp.ac.in
}

The change in the tropical forests could be clearly linked to the expansion of the human population and economies. An understanding of the anthropogenic forcing plays an important role in analyzing the impacts of climate change and the fate of tropical forests in the present and future scenario. In the present study, we analyze the impact of natural and anthropogenic factors in forest dynamics in Katerniaghat wildlife sanctuary situated along the Indo-Nepal border in Uttar Pradesh state, India. The study site is under tremendous pressure due to anthropogenic factors from surrounding areas since last three decades. The vegetation cover of the sanctuary primarily comprised of Shorea robusta forests, Tectona grandis plantation, and mixed deciduous forest; while the land cover comprised of agriculture, barren land, and water bodies. The classification accuracy was $83.5 \%, 91.5 \%$, and $95.2 \%$ with MSS, IKONOS, and Quickbird datasets, respectively. Shorea robusta forests showed an increase of $16 \mathrm{~km}^{2}$; while Tectona grandis increased by $63.01 \mathrm{~km}^{2}$ during 1975-2010. The spatial heterogeneity in these tropical vegetation classes surrounded by the human dominated agricultural lands could not be addressed using Landsat MSS data due to coarse spatial resolution; whereas the IKONOS and Quickbird satellite datasets proved to advantageous, thus being able to precisely address the variations within the vegetation classes as well as in the land cover classes and along the edge areas. Massive deforestation during 1970s along the adjoining international boundary with Nepal has led to destruction of the wildlife corridor and has exposed the wildlife sanctuary to interference like grazing and poaching. Higher rates of forest dynamics during the 25-year period indicate the vulnerability of the ecosystem to the natural and anthropogenic disturbances in the proximity of the sanctuary.

\section{Introduction}

Tropical forests play a crucial role in the global carbon and energy cycles. They support more than $50 \%$ of the described species and an even larger number of undescribed species (Dirzo and Raven 2003). With accelerated decline in biodiversity across the world, there is an urgent need to map and monitor the vegetation cover across different habitats and landscapes. An understanding of the anthropogenic forcing is crucial to analyze the effects of climate change and the fate of tropical forests (Wright 2005). Natural disturbances determine the forest dynamics and affect the tree diversity on local and regional scales (Pickett and White 1985; Clark 1992; Attiwill 1994; Sheil 1999),

Keywords. Tropical ecosystem; deforestation; forest dynamics; Quickbird; IKONOS. 
while anthropogenic disturbances contribute in regulating the regeneration dynamics, structure, and floristic composition of tropical ecosystems (Ewel et al. 1981; Horn and Hickey 1991). In most cases, changes in the structural attributes of the forests are related to disturbance regimes involving a single factor over a regional scale (Cannon et al. 1994; Scherer et al. 2000; Wright 2005). However, low-intensity disturbances such as firewood extraction and grazing, could involve the combined effect of multiple factors and result in ecosystem alteration, consequently leading to habitat degradation (Veblen 1978; Smiet 1992; Kappelle et al. 1996).

A priority area of research for the ecologists is the assessment and monitoring of biodiversity, which is essential in tropical habitats, where much of the world's species diversity is concentrated (Nagendra and Gadgil 1999; Sanchez-Azofeifa et al. 2003; Loarie et al. 2007). Wildlife protected areas (PAs) could provide the refuge to the endangered ecosystems and result in enhanced growth of the same. PAs in India have a relatively long history of forest management and exploitation as a majority of the PAs were originally reserved forests or other categories of government owned forests where focus of management was timber production, to meet the biomass demands of local communities, or soil and water conservation (Rodgers and Sawarkar 1988). During 1970's and 1980's, several reserved forests having high abundance of wildlife were noted/listed as national parks where exploitation of forest resources is entirely legally prohibited or as wildlife sanctuaries where a certain amount of exploitation and development may be permissible (Tripathi and Singh 2009).

Remote sensing datasets and techniques have long been utilized to predict species richness, based on environmental heterogeneity and derived by spectral heterogeneity (Palmer et al. 2002; Foody and Cutler 2003; Rocchini et al. 2004; HernándezStefanoni and Dupny 2007). While some success has been achieved, obviously, no single factor such as landscape heterogeneity or primary productivity drives biodiversity patterns (Turner et al. 2003). Instead, species are clustered based on some exogenous factors, such as climate and soil type. Such clustering or autocorrelation of species distribution is often on broad scales, facilitating the use of medium-coarse resolution imagery for species diversity estimations (Dormann 2007). Other biotic and abiotic processes may however cause further structuring within smaller areas of relative environmental homogeneity, giving rise to small scale niche patterning, and fine scale variations in biodiversity (Legendre 1993; Wagner 2003). In such cases, there is an apparent need for 'hyper-spatial' data.
When medium pixel resolution satellite datasets, a few tens of meters in size are used for ecological studies, a single pixel often encompasses a number of individual trees or plants, sometimes even crossing habitat boundaries (Small 2004). Thus each pixel corresponds to a mixed field signature averaged across multiple objects, leading to difficulties in identification of the species, or the mapping of fine scale variations in biodiversity. Hyperspatial satellite imagery is potentially much better suited for biodiversity mapping with pixel sizes of the size of $5 \mathrm{~m}$ or less, corresponding well to the size of individual tree crowns (Read et al. 2003; Wulder et al. 2004).

The region along the Himalayan foothills forms one of the distinct eco-climatic zones in northern India. The landscape is listed among the important eco-regions of the world, and is well known for its unique biodiversity and high productivity (Johnsingh et al. 2004). The region has undergone severe alterations due to the expansion of agricultural land, replacement of natural forests with commercial plantations, industrialization, and urbanization. It has caused fragmentation and degradation of natural habitats causing local extinction of several species. Due to its ecological importance as home to a large number of threatened and endangered flora and fauna species, the ecosystem has been studied by various researchers in terms of ecological studies and biodiversity assessments. Champion and Seth (1968) compared various communities associated with Shorea robusta forests along moisture gradients. Panigrahi et al. (1969) compared the flora of Terai forests and grasslands of Uttar Pradesh, India. The biotic pressures and their impact on regeneration and growth of wild plants in tropical moist deciduous forest of this region have been documented by Pandey (2000). Regeneration pattern and plant diversity in degraded Shorea robusta forest of northeastern Uttar Pradesh were assessed by Pandey and Shukla $(1999,2001)$. The structure of a rehabilitated forest established on barren land was studied in response to natural succession and degree of soil amelioration/land renewal over period of time (Tripathi 2001; Tripathi and Singh 2005). Several studies have analyzed community structure in Shorea robusta forests (Gupta and Shukla 1991; Singh et al. 1995, Pandey and Shukla 1999; Shankar 2001; Maliya and Singh 2003; Kumari and Tripathi 2007; Maliya 2007). Some of the patches in the region are drought prone and hence affect the regeneration rate of Shorea robusta. The plantations of Tectona grandis, Terminalia alata and Syzygium cumini were started mainly for gap filling and to replace poorly regenerating Shorea robusta species in some regions. 


\section{Materials and methods}

\subsection{Study area}

Katerniaghat wildlife sanctuary (KWS) was established in 1976 in Uttar Pradesh state of India, situated along the international boundary with Nepal. The sanctuary covers $400 \mathrm{~km}^{2}$ and is situated between $28^{\circ} 6^{\prime}-28^{\circ} 24^{\prime} \mathrm{N}$ latitude and $81^{\circ}$ $24^{\prime}-81^{\circ} 19^{\prime} \mathrm{E}$ longitude (figure 1a). KWS represents a distinctive Terai ecosystem characterized by alluvial plains, woodlands, moist deciduous forests, wetlands, and hygrophilous grasslands. KWS exhibits greater diversity by accommodating various vegetation classes, viz., moist deciduous forests (MDF), Tectona grandis plantations (TP), lowland swamp forest (LSF) and Savannah grasslands (SG). The MDFs can be further divided into Shorea robusta forests (SF) and mixed deciduous forests. Shorea robusta represents the climax species along with other associates such as Adina cordifolia Roxb. Hook. f., Syzygium cuminii L. Skeels, Terminalia alata Heyne ex Toth, Aegle marmelos L. Correa, Acacia catechu Willd., and Mallotus philippensis Lamk. Muell.-Arg. Tectona grandis was introduced during 1965-1966 in the drought-prone areas of KWS to replace Shorea robusta (Anon 2005). Although Tectona grandis is an artificially introduced species, it has adapted well to the local conditions and hence the plantations were continued in other drought affected areas of KWS. The growth rate of Tectona grandis was found to be slower in the regions of sandy and gravelly soils. Mammalian fauna of KWS includes Tiger (Panthera tigris), leopard (Panthera pardus), spotted deer (Axis axis), swamp deer (Cervus duvauceli duvauceli). The sanctuary is also rich in avifauna, common species being Little grebe (Podiceps ruficollis), black kite (Milvus migrans), black francolin (Francolinus francolinus), red jungle fowl (Gallus gallus), in addition, Gharial (Gavialis gangeticus), Crocodile (Crocodilus palustris), Gangetic softshell turtle (Aspidertus gangeticus) and most importantly the Gangetic river dolphin (MoEF 2010), which has been recently pronounced as India's 'National Aquatic Animal'. Main disturbance factors in KWS are a road and a narrow gauge railway line that traverse through the sanctuary thus causing a barrier between two forest fragments. KWS is situated along the IndiaNepal border and a major portion of the sanctuary faces human interference. The deforestation along KWS's boundary has destructed the wildlife corridor between KWS and adjoining Royal Bardia national park, Nepal, which is a major concern for Tiger conservation. Human-wildlife conflicts in the buffer region also pose a threat to the wildlife of KWS. The sanctuary is also affected by natural factors such as change in river course and floods in Girwa river, which result in forest cutting and sedimentation in few areas.

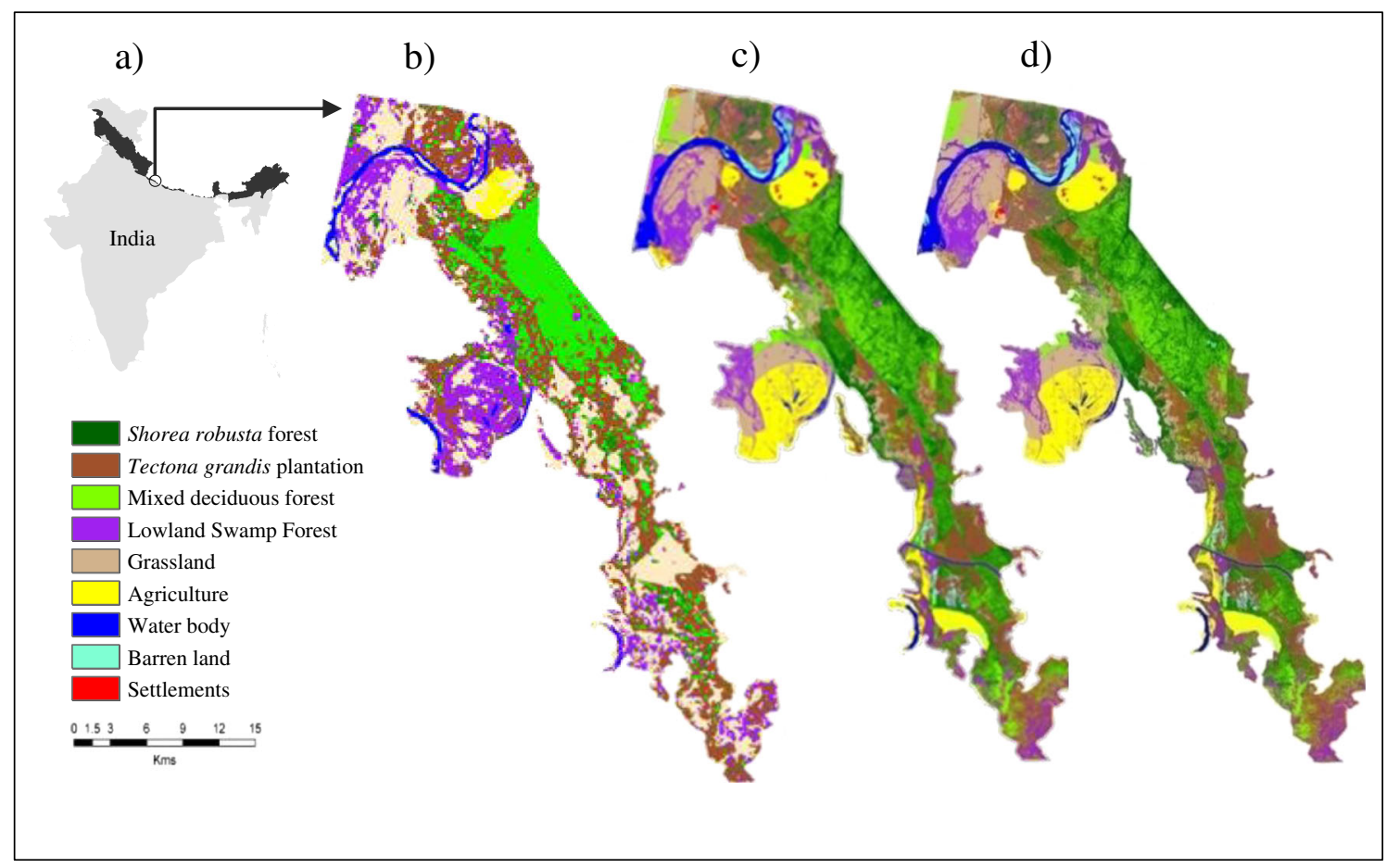

Figure 1. (a) The map indicates the location of Katerniaghat wildlife sanctuary (KWS) along Himalayan foothills; vegetation classification based on (b) Landsat MSS 16th March, 1975, (c) IKONOS year 2000, and (d) quickbird year 2010 . 


\subsection{Land/vegetation cover classification and dynamics}

In the present study, we analyzed the past and present status of KWS with the alterations in the forest vegetation and land cover classes in the Katerniaghat wildlife sanctuary (KWS) due to human interference and natural factors. The optical satellite datasets with variable spatial and temporal resolution were used in vegetation and land cover mapping of KWS. Due to unavailability of high resolution datasets, Landsat MSS satellite data with coarse resolution was used for the vegetation mapping of 1975 . The land cover of KWS was mapped under six vegetation and three non-vegetation classes using the satellite datasets for the 1975 Landsat MSS data (spatial resolution: $60 \mathrm{~m}$ ) of 16 March. Four tiles of multispectral IKONOS satellite data (spatial resolution: $4 \mathrm{~m}$ ) of year 2000 dating from 18 February to 21 March and four tiles of multispectral Quickbird satellite data (spatial resolution: $2.4 \mathrm{~m}$ ) of 2010 ranging from 28 February to 19 March were utilized in the study. The 'Equal area'- Lambert Conformal Conic LCC projection was maintained for all satellite datasets in order to keep the same area extent. The vegetation classification of Landsat MSS satellite data was carried out in Erdas Imagine 9.2 software and that of IKONOS and Quickbird satellite data was carried out in eCognition software v8.0. The land/vegetation cover classification process for the three time periods was based on the decision tree classifiers (Simard et al. 2000; Pavuluri et al. 2002) due to their capability to break down a complex decision-making process into a collection of simpler decisions, thus providing a simpler solution. Classification accuracy of all vegetation and land cover classes for all time periods was assessed by utilizing field sampling points acquired using global positioning system (GPS) during 2009-2011. Field reconnaissance tours were conducted during summer, post-rainfall, and winter season to account for the seasonal variations in the vegetation and to use the field details as interpretation keys for better vegetation identification and demarcation using all three datasets. The classified outputs for the years 1975, 2000, and 2010 were analyzed to study the land cover dynamics and its drivers in KWS. The change dynamics matrix was critically studied to see the changes in vegetation of KWS during 10 years from 2000 to 2010, 25 years from 1975 to 2000, and 35 years from 1975 to 2010 . The river dynamics of Girwa river was studied to analyze the role of nutrient load in the forest growth and net primary productivity. Human and nonhuman drivers inducing the land/vegetation cover change in KWS were analyzed based on the satellite datasets of
Landsat MSS, IKONOS, and Quickbird, meteorological datasets (Chitale et al. 2012). Ground truth inputs in the form of field photographs and GPS points acquired during the field reconnaissance surveys were utilized to analyze the impacts of human interference in KWS in the form of cattle grazing, fire wood collection and timber wood logging (figure 4). Published literature from previous studies (Johnsingh et al. 2004; Anonymous 2005; Tripathi and Singh 2009) was used to analyse the influence of human and non-human drivers on land/vegetation cover change. Based on the multitemporal satellite data, the effect of sedimentation on the growth and productivity of lowland swamp forest was studied. Rate of land and vegetation cover dynamics per year for all three time periods was assessed based on the area changed in square kilometers and number of years in each time interval.

\section{Results}

\subsection{Vegetation/land cover of KWS}

Katerniaghat wildlife sanctuary (KWS) accommodated five dominant vegetation classes and four non-vegetation classes across the landscape of approximately $400 \mathrm{~km}^{2}$. Very high resolution IKONOS and Quickbird satellite data-based vegetation map for the year 2000 and 2010 respectively, resulted in nine land/vegetation classes, comprising of Shorea robusta (Sal) forest, Tectona grandis (Teak) plantation, mixed deciduous forest (MD), lowland swamp forest (LS), Savanna grassland (GL), and nonvegetation classes, viz., barren land, water body, agriculture, and settlements (figure 1c and d). Due to coarse resolution Landsat MSS data for year 1975, it was not possible to account for the spatial heterogeneity of vegetation classes, hence broad scale map showed six vegetation and two nonvegetation classes (figure 1b). The disturbance drivers such as roads, railways, and human settlements were easy to demarcate in case of VHR satellite data, but were difficult to identify on the coarse resolution satellite data. The area was classified under five vegetation classes comprising of Shorea robusta forest (SF), Tectona grandis plantation (TP), mixed deciduous forest (MD), lowland swamp forest (LS), grassland (GL), and three land cover classes; forest blanks, water body, agriculture. The classification accuracy was $83.5 \%, 91.5 \%$, and $95.2 \%$ with MSS, IKONOS, and Quickbird datasets respectively (table $1 \mathrm{a}-\mathrm{c}$ ). SFs are dominated mainly by Sal (Shorea robusta), a major constituent in the top canopy along with other species, viz., Terminalia alata, Syzygium cumini, Anogeissus latifolia, and Haldina cordifolia. Mallotus phillipensis is found 
Table 1. Classification accuracy of land/vegetation cover maps of KWS.

\begin{tabular}{|c|c|c|c|c|c|c|c|c|c|c|c|c|}
\hline LULC class & $\mathrm{SF}$ & $\mathrm{TP}$ & MD & $\mathrm{LS}$ & GL & $\mathrm{AG}$ & FB & WB & BL & $\begin{array}{l}\text { Row } \\
\text { total }\end{array}$ & $\begin{array}{c}\text { User's } \\
\text { accuracy }(\%)\end{array}$ & $\mathrm{Kc}$ \\
\hline \multicolumn{13}{|c|}{ a) Landsat MSS data of 1975} \\
\hline $\mathrm{SF}$ & 22 & 3 & 2 & & 1 & & & & & 28 & 78.57 & 0.7 \\
\hline $\mathrm{TP}$ & 3 & 21 & & & & & & & & 24 & 87.50 & 0.8 \\
\hline MD & 2 & & 17 & 2 & & & & & & 21 & 80.95 & 0.7 \\
\hline $\mathrm{LS}$ & & & 2 & 9 & 1 & & & & & 12 & 75.00 & 0.7 \\
\hline GL & & & & 1 & 12 & 1 & & & 1 & 15 & 80.00 & 0.8 \\
\hline $\mathrm{AG}$ & & & & & & 18 & 3 & & & 21 & 85.71 & 0.7 \\
\hline FB & & & & & & 1 & 11 & & 1 & 13 & 84.62 & 0.7 \\
\hline WB & & & 1 & & & & & 17 & & 18 & 94.44 & 0.8 \\
\hline $\mathrm{BL}$ & & & & & & & 1 & 1 & 12 & 14 & 85.71 & 0.7 \\
\hline Column total & 27 & 24 & 22 & 12 & 14 & 20 & 15 & 18 & 14 & & & \\
\hline Producer's accuracy (\%) & 81 & 88 & 77 & 75 & 86 & 90 & 73 & 94 & 86 & & & \\
\hline \multicolumn{13}{|c|}{ Overall classification accuracy $=83.5 \%$} \\
\hline \multicolumn{13}{|c|}{ Overall Kappa coefficient $=0.73$} \\
\hline \multicolumn{13}{|l|}{ b) IKONOS data of 2000} \\
\hline $\mathrm{SF}$ & 25 & 1 & & & & & & & & 26 & 96.15 & 0.9 \\
\hline TP & 1 & 23 & & & & & & & & 24 & 95.83 & 0.9 \\
\hline $\mathrm{MD}$ & 1 & & 18 & 2 & & & & & & 21 & 85.71 & 0.8 \\
\hline $\mathrm{LS}$ & & & 1 & 10 & 1 & & & & & 12 & 83.33 & 0.8 \\
\hline GL & & & & & 13 & 1 & & & & 14 & 92.86 & 1 \\
\hline $\mathrm{AG}$ & & & & & & 19 & 2 & & & 21 & 90.48 & 1 \\
\hline FB & & & & & & & 12 & & 1 & 13 & 92.31 & 0.8 \\
\hline WB & & & 1 & & & & & 18 & & 19 & 94.74 & 0.9 \\
\hline $\mathrm{BL}$ & & & & & & & 1 & & 13 & 14 & 92.86 & 0.8 \\
\hline Column total & 27 & 24 & 20 & 12 & 14 & 20 & 15 & 18 & 14 & & & \\
\hline Producer's accuracy (\%) & 93 & 96 & 90 & 83 & 93 & 95 & 80 & 100 & 93 & & & \\
\hline \multicolumn{13}{|c|}{ Overall classification accuracy $=91.5 \%$} \\
\hline \multicolumn{13}{|c|}{ Overall Kappa coefficient $=0.87$} \\
\hline \multicolumn{13}{|l|}{ c) Quickbird data of 2010} \\
\hline $\mathrm{SF}$ & 25 & & 1 & & & & & & & 26 & 96.15 & 0.9 \\
\hline TP & 1 & 23 & & & & & & & & 24 & 95.83 & 0.9 \\
\hline $\mathrm{MD}$ & & 1 & 19 & 1 & & & & & & 21 & 90.48 & 0.8 \\
\hline LS & & & & 11 & 1 & & & & & 12 & 91.67 & 0.8 \\
\hline GL & & & & & 13 & 1 & & & & 14 & 92.86 & 1 \\
\hline $\mathrm{AG}$ & & & & & & 19 & 2 & & & 21 & 90.48 & 1 \\
\hline FB & & & & & & & 13 & & & 13 & 100.00 & 0.9 \\
\hline WB & & & & & & & & 19 & & 19 & 100.00 & 0.9 \\
\hline $\mathrm{BL}$ & & & & & & & & & 14 & 14 & 100.00 & 0.8 \\
\hline Column total & 26 & 24 & 20 & 12 & 14 & 20 & 15 & 19 & 14 & & & \\
\hline Producer's accuracy (\%) & 96 & 96 & 95 & 92 & 93 & 95 & 87 & 100 & 100 & & & \\
\hline \multicolumn{13}{|c|}{ Overall classification accuracy $=95.2 \%$} \\
\hline Overall Kappa coefficient & & & & & & & & & & & & \\
\hline
\end{tabular}

in abundance in middle storey. Due to its characteristic for resistance to fire and adaptability to various soil and site conditions, Shorea continues to retain its hold as a major species. Forest undergrowth in SF comprised of Ardisia solanacea, Colebrookia oppositifolia, Clerodendron viscosum, and Murraya koenighii. Dense growth of a liana Tiliacora acuminata was found in several patches. Considerable proportion of the area was found under forest plantations, where Teak constituted the dominant species. MDs supported a mixture of species comprising Terminalia alata (Asna), Anogeissus latifolia (Bakli), Syzygium cumini, Trewia nudiflora, Dalbergia sissoo, Ficus racemosa, and Acacia catechu in the top canopy, whereas Mallotus phillipensis, Millusa 
velutina, and Streblus asper occurred in the middle canopy. Shrub species like Clerodendrum viscosum and Glycosmis pentaphylla were also encountered. Lowland swamp forests (LS) occurred in swampy depressions which remain flooded during the rains or heavy waterlogged areas containing deep black soils with rich humus content. Poor soil aeration results in waterlogging that supports the dominant growth of tree species like Syzygium cumini. Other species, viz., Trewia nudiflora, Terminalia alata, and Lagerstromea parviflora were found along with shrubs like Clerodendrum viscosum, Glycosmis pentaphylla, and Murraya koenigii. Savannah/grasslands (GL) occupied large areas and accommodated scattered trees of Bombax ceiba, Syzygium cerasoides, Dalbergia sissoo, Haldina cordifolia, and Acacia catechu. The dominant grasses vary from place to place, depending mainly upon the soil type and drainage. Sclerostachya fusca and Arundo donax were in swampy locations, whereas Imperata cylindrica, Desmostachya bipinnata, Cymbopogon jwarancusa, and Saccharum spontaneum were found over clayey soil.

\subsection{Land/vegetation cover dynamics}

The land/vegetation cover dynamics was assessed in three sets 1975-2000, 2000-2010, and 1975-2010 (figure $1 \mathrm{~b}-\mathrm{d}$ ). Interesting results were observed in the change matrices due to variability of time periods. Increase in forest plantation was observed on year 2000 and 2010 datasets, where teak plantation replaced forest blank areas observed in 1975 datasets. An increase of $16 \mathrm{~km}^{2}$ was observed in Shorea robusta forests (table $2 \mathrm{a}-\mathrm{c}$ ). Tectona grandis (Teak) was introduced in 1965-1966 in the region to counter the problem of regeneration of Shorea robusta. The Tectona grandis plantations adapted well to the conditions and hence the plantation was continued during the subsequent years. Tectona grandis plantations showed the highest increase in the area, i.e., of $63.01 \mathrm{~km}^{2}$, whereas forest blanks showed the highest decrease, i.e., 73.91 $\mathrm{km}^{2}$ (figure 2a). Major decline was observed in MD, which could be accounted for by the difference in spatial resolutions of Landsat MSS and IKONOS satellite data. Due to coarser resolution of Landsat MSS satellite data, most of the patches of LSF were classified under MD, which resulted in the area of $121.51 \mathrm{~km}^{2}$ of MD, during the classification based on the VHR data it was found to be $76.47 \mathrm{~km}^{2}$. GL showed an increase of approximately $32.96 \mathrm{~km}^{2}$ from 1975 to 2000.

The land/vegetation cover dynamics was assessed for the time period from year 2000 to 2010 based on the VHR datasets of IKONOS and Quickbird satellite data respectively (figure 2a).
The vegetation classification showed precise demarcation and identification of the vegetation classes in KWS. Minimal changes were observed in Shorea robusta forests, Tectona grandis plantation and mixed deciduous forests. LSF showed a decrease of approximately $3.54 \mathrm{~km}^{2}$, which was replaced by GL at a few places indicating the ecological succession.

The time interval of 35 years 1975-2010 could highlight the major changes occurred in the sanctuary. Most of plantations would have undergone sound growth and the results would be evident by the period of 30-35 years. Due to coarser resolution of the Landsat MSS satellite data, addressing changes at higher spatial scales was not possible; however, the major changes broadly include increase in Shorea robusta forests, Tectona grandis plantations, and grasslands. Due to the resolution difference of the two satellite datasets, the mixed deciduous forests and lowland swamp forests showed a decrease of 45.04 and $19.63 \mathrm{~km}^{2}$ (figure 2a). The spatial heterogeneity in the vegetation classes and in the land cover classes such as human settlements surrounded by the agricultural lands could not be addressed using Landsat MSS data. The VHR data of Quickbird satellite proved to advantageous, thus being able to precisely identify, demarcate, and account for the variations within the vegetation classes as well as in the land cover classes and along the edge areas.

\subsection{Rate of vegetation dynamics}

The rate of land/vegetation cover dynamics was assessed based on the change in area per $\mathrm{km}^{2}$ per year. The rate of vegetation cover dynamics would highlight the resilience of the vegetation types of the ecosystem; and also provide an idea whether the artificially introduced plantation species are capable of sustaining in the present climate change scenario. Shorea robusta forests showed a progressive trend with the rate of dynamics of $0.20 \mathrm{~km}^{2}$ for 10 years, $0.63 \mathrm{~km}^{2}$ for 25 years, and $0.51 \mathrm{~km}^{2}$ for the period of 35 years (figure $2 \mathrm{~b}$ ). Tectona grandis plantation showed a prominent increasing trend with the rate of $-0.04 \mathrm{~km}^{2}$ for 10 years, 2.52 $\mathrm{km}^{2}$ for 25 years, and $1.78 \mathrm{~km}^{2}$ for the period of 35 years. The MD and LSF showed a declining trend for all three time periods; while GL exhibited an increasing trend for all three time periods. The rate of dynamics ranged from $0.45,1.31$, and $1.07 \mathrm{~km}^{2}$ for 10,25 , and 35 years respectively (figure $2 \mathrm{~b}$ ). The increasing trend of dynamics of river body in KWS points to the fact of river spread and course shift (figure 3a). The increase in the river body from 1975 to 2000 was approximately $5.02 \mathrm{~km}^{2}$ indicating river expansion and decrease in landmass. 
Table 2. Land/vegetation cover dynamics from year (a) 1975 to 2000, (b) 2000 to 2010 and (c) 1975 to 2010.

\begin{tabular}{|c|c|c|c|c|c|c|c|c|c|c|}
\hline a) & $\mathrm{SF}$ & $\mathrm{TP}$ & $\mathrm{MD}$ & LS & GL & $\mathrm{AG}$ & $\mathrm{FB}$ & WB & BL & 1975 \\
\hline $\mathrm{SF}$ & 41.57 & 4.77 & 19.76 & 2.79 & 0.19 & 0.40 & 0.56 & 0.03 & 0.28 & 70.36 \\
\hline $\mathrm{TP}$ & 0.32 & 6.31 & 4.63 & 1.65 & 0.48 & 0.07 & 0.00 & 0.01 & 0.00 & 13.47 \\
\hline $\mathrm{MD}$ & 19.58 & 12.63 & 60.15 & 13.33 & 10.23 & 2.82 & 4.11 & 1.08 & 0.22 & 121.51 \\
\hline LS & 2.50 & 3.21 & 14.14 & 5.71 & 27.65 & 11.29 & 4.89 & 7.15 & 0.26 & 75.60 \\
\hline GL & 1.46 & 1.29 & 6.94 & 1.97 & 6.64 & 0.90 & 6.16 & 0.33 & 0.11 & 24.78 \\
\hline$A G$ & 0.00 & 0.00 & 0.05 & 0.00 & 0.05 & 5.40 & 0.15 & 0.00 & 0.05 & 5.72 \\
\hline $\mathrm{FB}$ & 2.98 & 24.82 & 23.91 & 6.57 & 19.68 & 10.79 & 13.24 & 7.19 & 0.00 & 107.61 \\
\hline WB & 0.19 & 0.15 & 0.62 & 0.49 & 3.05 & 0.15 & 1.47 & 6.15 & 0.16 & 12.45 \\
\hline $\mathrm{BL}$ & 0.16 & 0.12 & 0.52 & 0.17 & 0.69 & 0.54 & 0.15 & 0.23 & 0.00 & 2.57 \\
\hline 2000 & 68.76 & 53.30 & 130.72 & 32.68 & 68.66 & 32.36 & 30.73 & 22.17 & 1.08 & 434.07 \\
\hline b) & SF & $\mathrm{TP}$ & $\mathrm{MD}$ & $\overline{L S}$ & GL & $\mathrm{AG}$ & WB & $\mathrm{BL}$ & ST & 2000 \\
\hline$\overline{\mathrm{SF}}$ & 85.57 & 0.14 & 0.26 & 0.12 & 0.11 & 0.02 & 0.04 & 0.00 & 0.00 & 86.26 \\
\hline $\mathrm{TP}$ & 0.00 & 75.59 & 0.67 & 0.00 & 0.22 & 0.00 & 0.00 & 0.00 & 0.00 & 76.48 \\
\hline MD & 2.50 & 0.00 & 71.44 & 1.27 & 1.26 & 0.00 & 0.00 & 0.00 & 0.00 & 76.47 \\
\hline LS & 0.05 & 0.25 & 4.21 & 52.79 & 1.59 & 0.49 & 0.04 & 0.09 & 0.00 & 59.51 \\
\hline GL & 0.01 & 0.00 & 0.00 & 0.12 & 56.82 & 0.41 & 0.00 & 0.34 & 0.04 & 57.74 \\
\hline $\mathrm{AG}$ & 0.00 & 0.00 & 0.00 & 1.61 & 2.29 & 45.94 & 0.01 & 0.02 & 0.05 & 49.92 \\
\hline WB & 0.16 & 0.00 & 0.00 & 0.01 & 0.00 & 0.00 & 17.29 & 0.01 & 0.00 & 17.47 \\
\hline BL & 0.05 & 0.00 & 0.00 & 0.04 & 0.00 & 0.00 & 0.00 & 7.88 & 0.00 & 7.97 \\
\hline $\mathrm{ST}$ & 0.00 & 0.02 & 0.00 & 0.00 & 0.00 & 0.00 & 0.00 & 0.00 & 0.80 & 0.82 \\
\hline 2010 & 88.34 & 76.00 & 76.58 & 55.96 & 62.29 & 46.86 & 17.38 & 8.34 & 0.89 & 432.64 \\
\hline c) & $\mathrm{SF}$ & $\mathrm{TP}$ & $\mathrm{MD}$ & LS & GL & $\mathrm{AG}$ & WB & $\mathrm{BL}$ & $\mathrm{ST}$ & 1975 \\
\hline$\overline{\mathrm{SF}}$ & 85.57 & 0.14 & 0.26 & 0.12 & 0.11 & 0.02 & 0.04 & 0.00 & 0.00 & 70.36 \\
\hline $\mathrm{TP}$ & 0.00 & 75.59 & 0.67 & 0.00 & 0.22 & 0.00 & 0.00 & 0.00 & 0.00 & 13.47 \\
\hline MD & 2.50 & 0.00 & 71.44 & 1.27 & 1.26 & 0.00 & 0.00 & 0.00 & 0.00 & 121.51 \\
\hline LS & 0.05 & 0.25 & 4.21 & 52.79 & 1.59 & 0.49 & 0.04 & 0.09 & 0.00 & 75.60 \\
\hline GL & 0.01 & 0.00 & 0.00 & 0.12 & 56.82 & 0.41 & 0.00 & 0.34 & 0.04 & 24.78 \\
\hline $\mathrm{AG}$ & 0.00 & 0.00 & 0.00 & 1.61 & 2.29 & 45.94 & 0.01 & 0.02 & 0.05 & 5.72 \\
\hline WB & 0.16 & 0.00 & 0.00 & 0.01 & 0.00 & 0.00 & 17.29 & 0.01 & 0.00 & 107.61 \\
\hline BL & 0.05 & 0.00 & 0.00 & 0.04 & 0.00 & 0.00 & 0.00 & 7.88 & 0.00 & 12.45 \\
\hline $\mathrm{ST}$ & 0.00 & 0.02 & 0.00 & 0.00 & 0.00 & 0.00 & 0.00 & 0.00 & 0.80 & 2.57 \\
\hline 2010 & 88.34 & 76.00 & 76.58 & 55.96 & 62.29 & 46.86 & 17.38 & 8.34 & 0.89 & 434.07 \\
\hline
\end{tabular}

SF: Shorea robusta forest, TP: Tectona grandis plantation, MD: moist deciduous forest, LS: lowland swamp forest, GL: grassland, AG: agriculture, FB: forest blanks, WB: water body, BL: barren land.

\subsubsection{Land/vegetation dynamics drivers}

\section{Human-induced drivers}

- Forest plantations - Human induced drivers put forth positive and negative consequences, which alter the composition of the ecosystem. In KWS, the forest plantations of Tectona grandis and Eucalyptus citriodora undertaken regularly by the State Forest Department (SFD) proved to be supportive to the ecosystem by maintaining the forest density. The results of the SFD efforts can be seen by the increase in the forest cover (figure 3a), which would result in higher carbon sequestration.

- Deforestation and human intervention - Diverse Shorea robusta forests situated along the
Indo-Nepal border are facing tremendous anthropogenic pressure due to the ever-increasing human interference by the Nepal residents. The forest corridor between Katerniaghat wildlife sanctuary, India and Bardia national park, Nepal was destructed due to major deforestation undertaken by Nepal government during the postindependence period (figure $3 \mathrm{~b}$ ). This has led to increase in human interference in the sanctuary, which may result in deforestation, poaching, and human-wildlife conflicts.

- Human-wildlife conflict - Katerniaghat WLS, Dudhwa national park, and Kishanpur WLS are the important protected areas (PAs) in the Terai landscape of Uttar Pradesh, India. There is always an active interaction between protected areas and landscapes surrounding them 


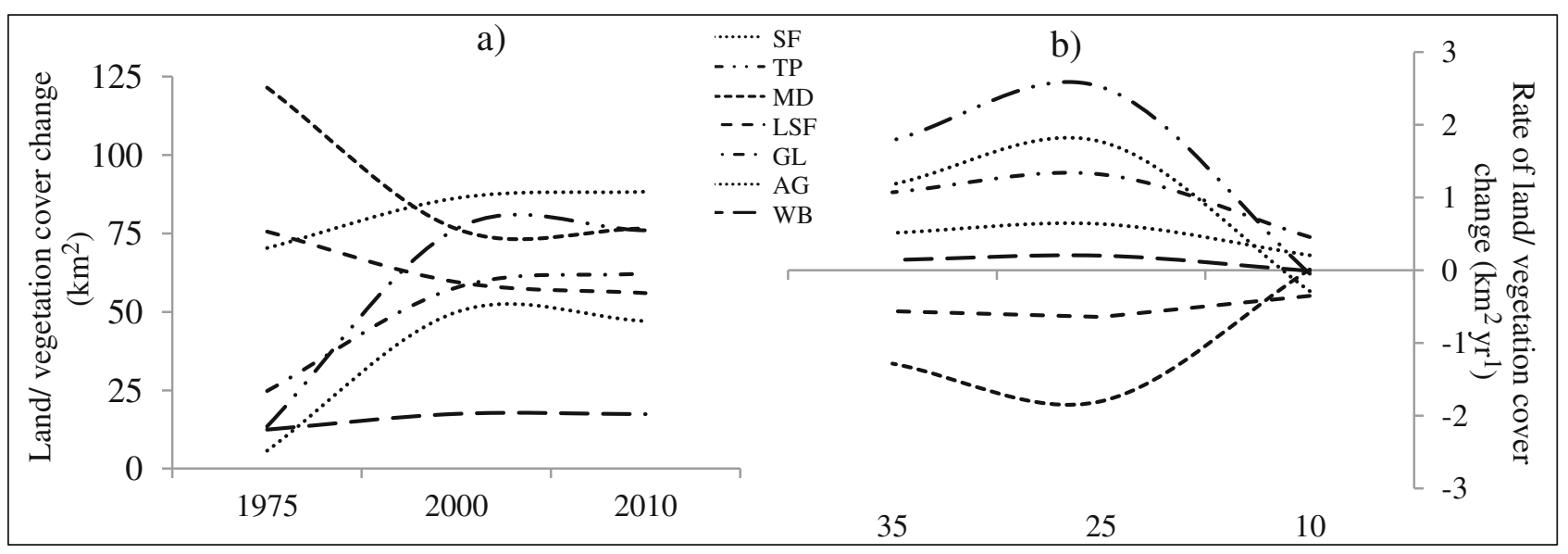

Figure 2. (a) The land/vegetation cover dynamics from 1975 to 2000 and 2010 shows a positive trend except for the mixed deciduous forests; (b) the rate of land/vegetation cover dynamics was highest for the Tectona grandis plantation, grasslands and Shorea robusta forests, the declining trend was observed for the mixed deciduous forests and lowland swamp forests.

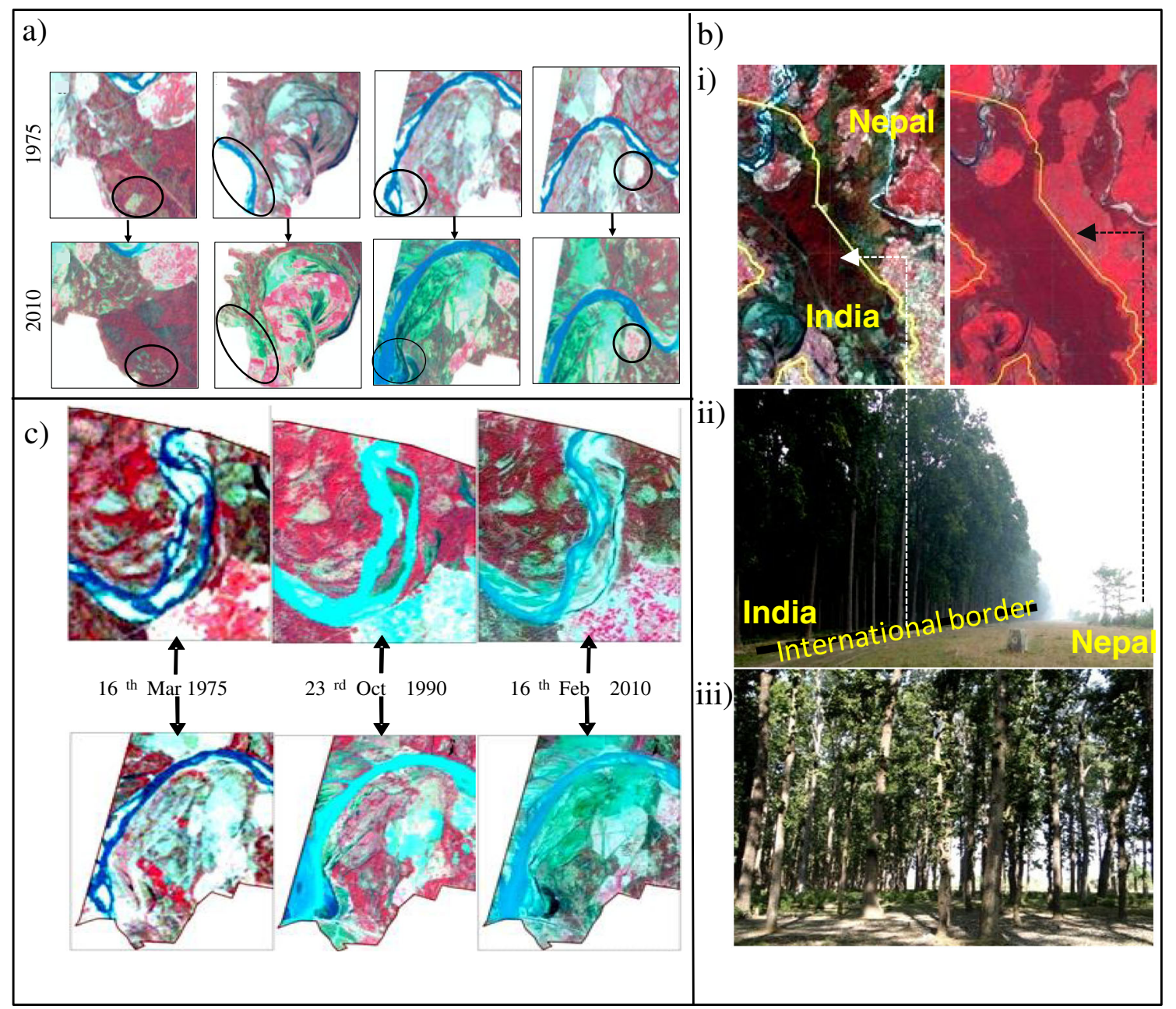

Figure 3. (a) Land and vegetation cover dynamics as seen from satellite datasets of year 1975 and 2010 . (b-i) Change detection analysis indicating major deforestation along the Nepal border as seen in Landsat MSS image of 1975 and Landsat TM image of 2010. (b-ii) Field photograph from 'No man's Land' shows Shorea robusta forests in India and deforested land in Nepal. (b-iii) Effect of deforestation of the forest diversity showing dominant Sal forest without the undergrowth unlike the Shorea forests in other regions of the sanctuary vegetation/land cover changes during 1975 and 2010 . (c) Multitemporal satellite datasets indicate change in river course and floods in Girwa river resulting in landmass removal and sedimentation respectively. 
A)
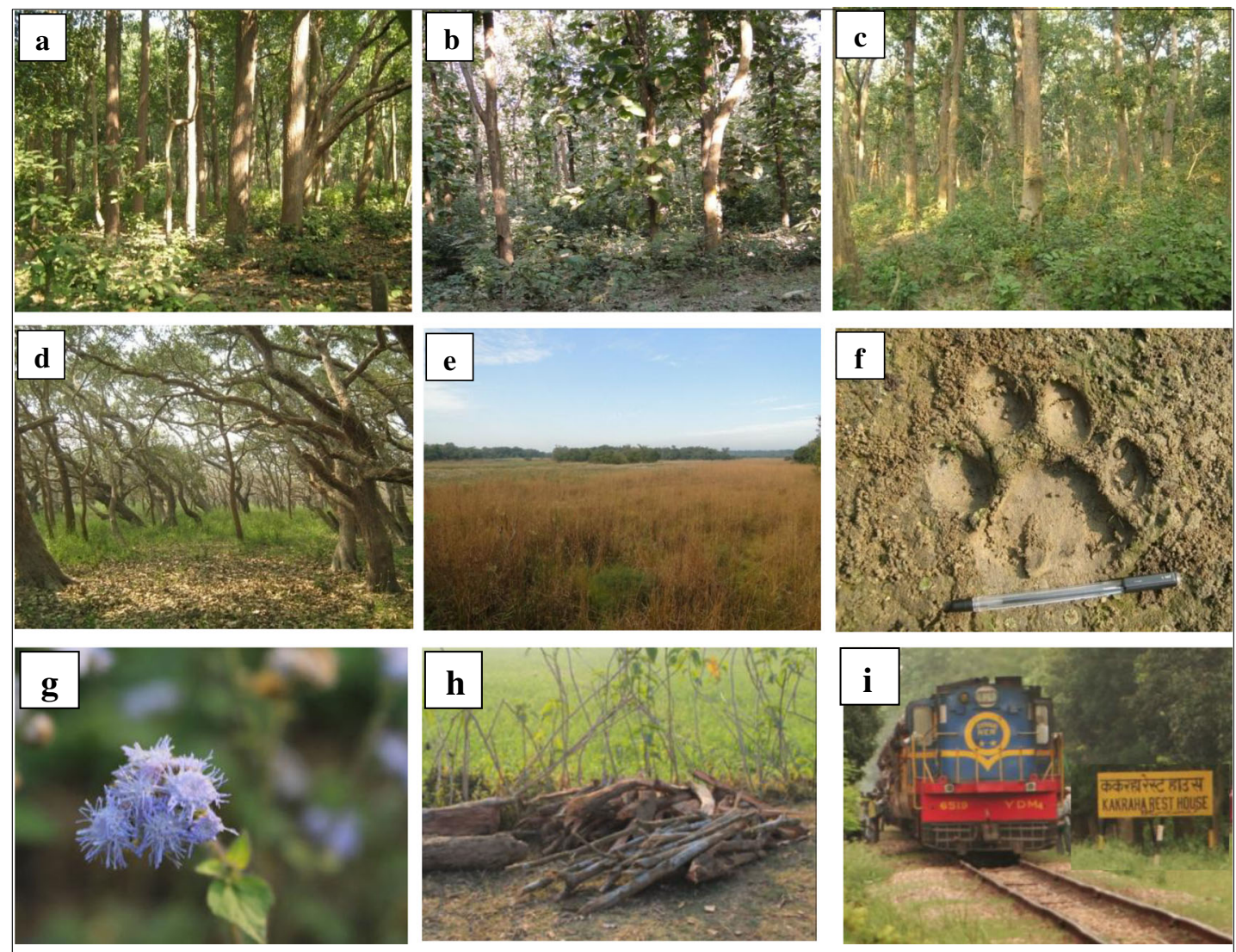

B)

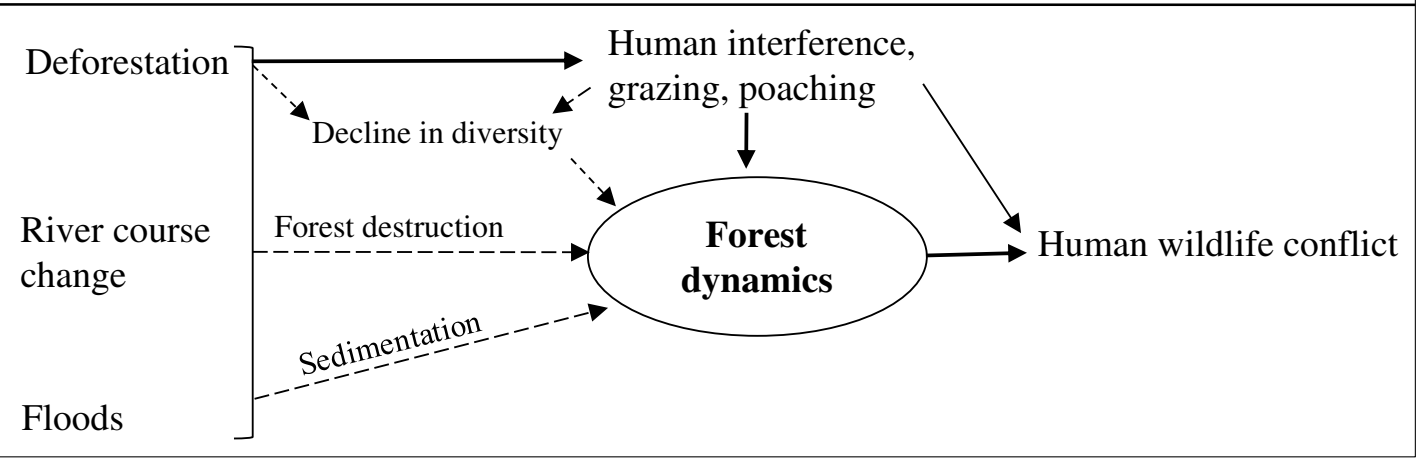

Figure 4. (A) Field photographs indicating biodiversity of KWS and factors responsible for habitat degradation; (a) Shorea robusta forest, (b) Tectona grandis plantation, (c) Mixed deciduous forest, (d) Lowland forest, (e) Grassland, (f) Tiger pugmark recorded on 16th December 2011, (g) Eupatorium odoratum invasive plant, (h) firewood collected along the buffer region of KWS, (i) the railway track cutting the sanctuary longitudinally. (B) Natural and anthropogenic disturbance factors result in elevated rates of forest dynamics.

for maintaining the flows of organisms, water, nutrients, and energy. Satellite image-based analyses indicate that land use change is occurring in lands surrounding protected areas throughout the world, particularly the tropics (DeFries et al. 2005). Typically, communities living in and around these PAs are financially poor and rely on the local ecosystem for fuel wood, fodder, water, and other ecosystem services. The common perception of human-dominated landscapes in the tropics is dependent on ecosystem, subsistence or small-market farmers. There is an urgent need for regional-scale land use planning for the regions surrounding protected areas and human-dominated landscapes to balance conservation goals with livelihood needs for fuel wood, fodder, and other ecosystem services.

\section{Natural drivers}

- Change in river course and floods - KWS faces threat due to the river course shift and channel expansion of Girwa river, mainly caused due to excessive flooding during rainy season. Floods during rainy season have caused major devastation in the areas in the vicinity of the sanctuary 
during last 5-6 years. The river flows through the northern part of the region, which is the natural habitat for the crocodile, alligator, and Gangetic river dolphin; which has been declared as 'national aquatic animal' of India. Shift in river course can be clearly seen from the Landsat datasets of 1975 and 2010 (figure 3c). The landscape is dominated by alluvial soil which makes it prone to erosion (Kale 1998). The mid-river inlands of the Girwa river have been the nesting place of rare alligators since last many years, which is being destructed due to expansion and flooding of the river channel. The wildlife sanctuary was severely affected due to occurrence of flash floods in August 2009, the main cause of which was the huge amount of water discharge from Nepal. Over 400,000 cusec water was believed to have reached Uttar Pradesh during that period. Many regions have been significantly affected due to the devastating floods. Excess water flow from the upper reaches of rivers coming from Nepal is likely to worsen the situation in some areas. Proper disaster management plans need to be implemented to cope with such disasters. The mountain-fed streams originate in the Himalaya and have large basin areas in the mountains. The Kosi River, for example, has shifted by over a $100 \mathrm{~km}$ in the last 200 years or so (Sinha and Friend 1994). The rivers of the Indus-Ganga-Brahmaputra plains carry more than 2-3 orders of magnitude higher water and sediment discharge during floods than the nonmonsoon low flows. The rivers have a wide floodplain on both the sides of the nonmonsoon low flow channel. In the eastern parts of the Gangetic plain, the floodwater inundates the floodplains at least once in two years (Asthana-and-Bhargava 1981). The low flow channels frequently change their courses during monsoon floods, by avulsion or by bank cutting. It has been postulated that floods with a recurrence interval of 5 or more years are responsible for major changes in the courses of the rivers in the Ganga Plains (Richardson and Thorne 2001). Any flood management plan has to conform to local conditions and has to be cost-effective, apart from minimizing the adverse effects of flood control measures such as modifications in river sections, waterlogging, and increased development in floodplains to avoid greater damages during flooding (Jain and Sinha 2003).

- Sedimentation in LSFs - The Girwa river has resulted in sedimentation in LSFs located along the riverbanks (figure 3c) and has added to nutrient content of the ecosystem; which has lead to increment in the net primary productivity of LSFs (Chitale et al. 2012). The river, however, has lead to the forest destruction by landmass removal as indicated by the land cover dynamics of $5.42 \mathrm{~km}^{2}$ due to river course shift.

\section{Discussion and conclusions}

\subsection{Land/vegetation cover dynamics}

In the present study, we analyze the impact of natural and anthropogenic factors in forest dynamics in a protected ecosystem situated along the Himalayan foothills in India. Tropical ecosystems have been studied during past studies using geospatial techniques for assessing the biodiversity, ecosystem function, and impacts of climate change on the ecological components of the ecosystems (Rodgers and Sawarkar 1988; Johnsingh et al. 2004; De Fries et al. 2005). Most of the studies were based on medium-to-coarse resolution satellite datasets, which limit the classification accuracy of the vegetation mapping. In the present era of forest degradation and deforestation, highly accurate vegetation cover maps and statistics form important sources of base data for the conservationists and ecologists. Increase in classification accuracy of all land and vegetation cover classes was apparent with IKONOS and Quickbird datasets in comparison to Landsat MSS, since higher spatial resolution in the former datasets facilitated better discrimination of forest and nonvegetation classes. Land/vegetation cover dynamics indicated increase in forest cover pertaining to increased forest plantations. Although Tectona grandis and other plantation species have well adapted to the local physiographic conditions, the species have altered the diversity of the ecosystem. Unlike natural forests, such artificially introduced plantations would not support the ground flora and hence result in decline in plant diversity, increasing risk of soil erosion and floods. The decline in ground flora of TP has resulted in decreased moisture levels as compared to SF and MD. The plantations of exotic species could be replaced by artificial regeneration of the native species such as Shorea robusta, which supports the ground flora and could maintain the diversity of the ecosystem.

The forested ecosystems are facing the challenge for maintaining pace with inclining rates of dynamics. Anthropogenic activities alone are not responsible for the forest dynamics; however various natural factors also contribute to the process. In this scenario, we chose to assess the rate of land/vegetation cover dynamics in a tropical ecosystem. The rates of land/vegetation cover dynamics indicate the response of ecosystems to natural and anthropogenic drivers. Lower rates of dynamics in SF indicate dominance of the species along the Himalayan foothills. Higher rates of 
change were observed during longer time periods, because the plantations of Tectona grandis were carried out on a major scale in the region during the period. GL exhibited an increasing trend during all three time periods. The inclining trend of GL indicates two facts: (i) fastening of the ecological succession in the ecosystem, (ii) degradation of the ecosystem/ decline in the ecosystem health. The increase in GL could be linked to the degradation of the ecosystem health; however GLs are the most suitable places for large mammals such as Tigris tigris. The increase in GL could improve the survival rates of the big cats by providing them abundant prey.

\subsubsection{Land/vegetation dynamics drivers}

We analyzed the role of natural and anthropogenic drivers in land/vegetation cover dynamics. The State Forest Department is putting maximum effort in ecosystem conservation by undertaking forest plantations, maintaining the forest nurseries to maintain the seed bank, and keeping the ecosystem under persistent surveillance to protect it from the human interference. The other side of humaninduced drivers, however, does not prove to be advantageous to KWS. Road and railway networks traversing through KWS pose a threat to the sanctuary by destructing the wildlife corridor and forest destruction makes previously inaccessible areas accessible. Shorea robusta forests, which are situated along the Indo-Nepal border, are exposed to higher levels of anthropogenic pressure due to the ever-increasing human interference by residents of Nepal. Forest corridor between Katerniaghat wildlife sanctuary, India and adjoining Bardia national park, Nepal was destructed due to major deforestation undertaken by Nepal government during 1970s (figure 3b). For the purpose of revenue generation and to provide land area for human settlements; Nepal government undertook massive forest felling. This has proved to be destructive for the forested ecosystems situated in the Indian region along the Nepal border. Check posts set up by SFD on the traversing roads maintain the records of vehicles passing through KWS and prevent smuggling and illegal transport of timber wood and wildlife.

Katerniaghat WLS, Dudhwa national park, and Kishanpur WLS are some of the important protected areas (PAs) in the Terai landscape of Uttar Pradesh along the Indo-Nepal border. These areas face tremendous anthropogenic pressure from all sides of the boundary, which makes them vulnerable to human-wildlife conflicts (figure $4 \mathrm{a}$ and $\mathrm{b}$ ). There is always an active interaction between protected areas and landscapes surrounding them for maintaining the flows of organisms, water, nutrients, and energy. There have been frequent attacks by wild animals on the livestock from the villages in the proximity of PAs. Crops in the agricultural fields situated in the surroundings of the PAs are often destroyed by the herds of deer (Axis axis) and antelope (Boselaphus tragocamelus). Scientificallybased regional land use planning is needed to balance human needs and conservation goals in the larger landscape. Natural drivers of dynamics include change of river course and floods, which cause major devastation of the human settlements, agricultural lands, and forests. During the last few years, the floods have caused massive destruction of the forests (Reuters India, September 23, 2008, Asian News International, August 25, 2009, Times of India, September 22, 2010). Mid-river inlands of the Girwa river have been the nesting place of alligators for long, which is affected due to expansion and flooding of the river channel. Stone/tyre pitching, hard armoring, and bioengineering could be implemented to cope with the river bank erosion, which cuts the forest land every year. Girwa river has affected KWS resulting in sedimentation in LSFs located along the river banks and has added to nutrient content of the ecosystem, leading to increment in the net primary productivity of LSFs (Chitale et al. 2012). Our study highlights present status of a diverse tropical ecosystem located along Himalayan foothills, which indicates habitat loss due to natural and anthropogenic factors. Higher rates of forest dynamics observed during the long-term vegetation dynamics indicate the vulnerability of the ecosystem to the natural and anthropogenic disturbances in the proximity of the sanctuary. High resolution satellite datasets proved to be advantageous in precise vegetation classification, which could be utilized for mapping and monitoring of forest ecosystems.

\section{Acknowledgements}

The present study is carried out under the CSIR network project in collaboration with NBRI, Lucknow. The authors are thankful to the financial support provided by CSIR, Dr C S Nautiyal, Director, NBRI and S K Behera, Scientist, NBRI for their kind support and encouragement. The Landsat MSS satellite datasets downloaded from USGS are thankfully acknowledged. They are thankful to ICIMOD, Nepal for the facilities provided during the final phase of the manuscript. The authors are also thankful to two anonymous reviewers for their valuable comments on the earlier version of the manuscript. 


\section{References}

Anonymous 2005 Management Plan of the Katerniaghat Wildlife Sanctuary 2005-2015; Uttar Pradesh Forest Department, Lucknow.

Asian News International, August 25, 2009.

Asthana B N and Bhargava A N 1981 Dominant discharge for alluvial rivers; Irr. Power J. 38 65-68.

Attiwill P M 1994 The disturbance of forest ecosystems: The ecological basis for conservative management; Forest Ecol. Manag. 63(2-3) 247-500.

Cannon C H, Peart D R, Leighton M and Kartawinata K 1994 The structure of lowland rainforest after selective logging in West Kalimantan, Indonesia; Forest Ecol. Manag. 67 49-68.

Champion H G and Seth S K 1968 Revised survey of forest types of India; Manager of Publications; Government of India, Delhi.

Chitale V S, Tripathi P, Behera M D, Behera S K and Tuli $\mathrm{R} 2012$ On the relationships among diversity, productivity and climate from an Indian tropical ecosystem: A preliminary investigation; Biodivers. Conserv. $211177-$ 1197.

Clark D B 1992 The role of disturbance in the regeneration of neotropical moist forests; In: Reproductive Ecology of Tropical Forest Plants (eds) Bawa K S and Hadley M, UNESCO-Parthenon, New York, Man and the Biosphere Series 7 291-315.

DeFries R, Hansen A J, Newton A C and Hansen M C 2005 Increasing isolation of protected areas in tropical forests over the past twenty years; Ecol. Appl. 15 19-26.

Dirzo R and Raven P H 2003 Global state of biodiversity and loss; Ann. Rev. Environ. Resour. 28 137-167.

Dormann C F 2007 Effects of incorporating spatial autocorrelation into the analysis of species distribution data; Global Eco. Biogeogr. 16 129-138.

Ewel J, Berish C, Brown B, Price N and Raich J 1981 Slash-and-burn impacts on a Costa Rican wet forest site; Ecology 62 816-829.

Foody G M and Cutler M E J 2003 Tree biodiversity in protected and logged Bornean tropical rain forests and its measurement by satellite remote sensing; J. Biogeogr. 30 1053-1066.

Gupta O P and Shukla R P 1991 The composition and dynamics of associated plant communities of sal plantations; Tropical Ecol. 32 296-309.

Hernández-Stefanoni J L and Dupny J M 2007 Mapping species density of trees, shrubs and vines in a tropical forest, using field measurements, satellite multispectral imagery and spatial interpolation; Biodivers. Conserv. 16 3817-3833.

Horn R and Hickey J 1991 Ecological sensitivity of Australian rainforests to selective logging; Aust. J. Ecol. 16 119-129.

Jain V and Sinha R 2003 Geomorphic manifestation of the flood hazard: A remote sensing based approach; Geocarto Int. 184 51-60.

Johnsingh A J T, Ramesh K, Qureshi Q, David A, Goyal S P, Rawat G S, Rajapandian K and Prasad S 2004 Conservation status of tiger and associated species in the Terai Arc Landscape, India, RR-04/001, Wildlife Institute of India, Dehradun, pp. viii +110 .

Kale V S 1998 Monsoon floods in India: A hydro-geomorphic perspective; In: Flood Studies in India (ed.) Kale V S, Geol. Soc. India Memoir 41 229-256.

Kappelle M, Geuze T, Leal M E and Cleef A M 1996 Successional age and forest structure in a Costa Rican upper montane Quercus forest; J. Trop. Ecol. 12 681698.
Kumari A and Tripathi K P 2007 Phytosociological studies of the pteridophytes in Terai forest of North India; Ind. J. Forestry 30 445-450.

Legendre P 1993 Spatial autocorrelation: Trouble or new paradigm? Ecology 74 1659-1673.

Loarie S R, Joppa L N and Pimm S L 2007 Satellites miss environmental priorities; Trends Ecol. Evol. 22 630-632.

Maliya S D 2007 Rare species of Katerniaghat Wild Life Sanctuary, District Bahraich, Uttar Pradesh, India; The Indian Forester 133 1052-1056.

Maliya S D and Singh K K 2003 Some new or less known folk medicines of Bahraich district, Uttar Pradesh; Ethnobotany 15 132-135.

Notification 18th May, 2010, Ministry of Environment and Forests, Government of India; http://moef.nic.in/ downloads/public-information/Dolphins_press_n.pdf.

Nagendra H and Gadgil M 1999 Biodiversity assessment at multiple scales: Linking remotely sensed data with field information; Proc. Natl. Acad. Sci. USA 96 9154-9158.

News paper The Hindu, Thursday, August 31, 2006, Uttar Pradesh.

Palmer M W, Earls P, Hoagland B W, White P S and Wohlgemuth T 2002 Quantitative tools for perfecting species lists; Environmetrics 13 121-137.

Pandey S K 2000 Population status and regeneration strategy of some perennial legumes in plantation forests of north-eastern Uttar Pradesh; Ph.D. Thesis, DDU Gorakhpur University, Gorakhpur, India.

Pandey S K and Shukla R P 1999 Plant diversity and community patterns along the disturbance gradient in plantation forests of sal Shorea robusta Gaertn. f; Curr. Sci. $77814-818$.

Pandey S K and Shukla R P 2001 Regeneration strategy and plant diversity status in degraded sal forests; Curr. Sci. 81 95-102.

Panigrahi G, Singh A N and Misra O P 1969 Contribution to the Botany of the Terai Forest of the Bahraich District of Uttar Pradesh; Bull. Bot. Surv. India 11 89-114.

Pavuluri M K, Ramanathan S and Daniel Z 2002 A rulebased classifier using classification and regression tree CART approach for urban landscape dynamics; Int. Geosci. Remote Sens. Symp. 2 24-28.

Pickett S T A and White P S 1985 The Ecology of Natural Disturbance and Patch Dynamics; Academic Press, New York.

Read J M, Clark D B, Venticinque E M and Moreira M P 2003 Application of 1-m and 4-m resolution satellite data to research and management in tropical forests; J. Appl. Ecol. 40 592-600.

Reuters India, September 23, 2008.

Richardson W R and Thorne C R 2001 Multiple thread flow and channel bifurcation in a braided river: BrahmaputraJamuna River, Bangladesh; Geomorphology 38 185-196.

Rocchini D, Chiarucci A and Loiselle S A 2004 Testing the spectral variation hypothesis by using satellite multispectral images; Acta Oecologica. 26 117-120.

Rodgers W A and Sawarkar V B 1988 Vegetation management in wildlife protected areas in India; Aspects Appl. Biol. 16 407-422.

Sanchez-Azofeifa G A, Castro K L, Rivard B, Kalascka M R and Harriss R C 2003 Remote sensing research priorities in tropical dry forest environments; Biotropica 35 134142.

Scherer G, Zabowski D, Java B and Everett R 2000 Timber harvesting residue treatment. Part II. Understory vegetation response; Forest Ecol. Manag. 126 $35-50$.

Shankar U 2001 A case of high tree diversity in a sal Shorea robusta-dominated lowland forest of Eastern Himalaya: 
Floristic composition, regeneration and conservation; Curr. Sci. 81 776-786.

Sheil D 1999 Tropical forest diversity, environmental change and species augmentation: After the intermediate disturbance hypothesis; J. Vegetation Sci. 10 851-860.

Simard M, Saatchi S and De Grandi F 2000 The use of decision tree and multiscale texture for classification of JERS-1 SAR data over tropical forest; IEEE Trans. Geosci. Remote Sens. 38 2310-2321.

Singh A, Reddy V S and Singh J S 1995 Analysis of woody vegetation of Corbett National Park, India; Vegetatio 120 69-79.

Sinha R and Friend P F 1994 River systems and their sediment flux, Indo-Gangetic plains, northern Bihar, India; Sedimentology 41 825-845.

Small C 2004 The Landsat $\mathrm{ETM}^{+}$spectral mixing space; Remote Sens. Environ. 93 1-17.

Smiet A C 1992 Forest ecology on Java: Human impact and vegetation on montane forest; J. Trop. Ecol. 8 129-152.

Times of India, September 22, 2010.

Tripathi K P 2001 Ecology of a Rehabilitated Forest on Sodic Wasteland; Ph.D. Thesis, Lucknow University, Lucknow.
Tripathi K P and Singh B 2005 The role of revegetation for rehabilitation of sodic soils in semiarid subtropical forest, India; Restoration Ecol. 13 29-38.

Tripathi K P and Singh B 2009 Species diversity and vegetation structure across various strata in natural and plantation forests in Katerniaghat Wildlife Sanctuary; Tropical Ecol. 501 191-200.

Turner W, Spector S, Gardiner N, Fladeland M, Sterling E and Steininger M 2003 Remote sensing for biodiversity science and conservation; Trends Ecol. Evol. 18 306-314.

Veblen T 1978 Forest preservation in the highlands of Guatemala; Geogr. Rev. 68 417-434.

Wagner H H 2003 Spatial covariance in plant communities: Integrating ordination, geostatistics, and variance testing; Ecology 84 1045-1057.

Wright S J 2005 Tropical forests in a changing environment; Trends Ecol. Evol. 20 553-560.

Wulder M A, Franklin S E, White J, Cranny M and Dechka J 2004 Inclusion of topographic attributes in an unsupervised classification of satellite imagery; Canadian J. Remote Sens. 30 137-149. 